\title{
Vallitalea guaymasensis gen. nov., sp. nov., isolated from marine sediment
}

\author{
Raja Lakhal $^{1}{ }^{2}$, Nathalie Pradel $^{1}$, Anne Postec ${ }^{1}$, Moktar Hamdi $^{2}$, Bernard Ollivier ${ }^{1}$, Anne Godfroy $^{3}$ \\ and Marie-Laure Fardeau ${ }^{1,}$
}

\footnotetext{
${ }^{1}$ Laboratoire de Microbiologie, IRD, Aix-Marseille Université, Université du Sud Toulon-Var, CNRS/INSU, IRD, MIO, UM 110, Case 925, 163 Avenue de Luminy, 13288 Marseille Cedex 9, France

2 Laboratoire d'Ecologie et de Technologie Microbienne, Institut National des Sciences Appliquées et de Technologie, Centre Urbain Nord, BP 676, 1080 Tunis Cedex, Tunisia

${ }^{3}$ Laboratoire de Microbiologie des Environnements Extrêmes, UMR 6197, IFREMER, 29280 Plouzané, France

*: Corresponding author : Marie-Laure Fardeau, email address : marie-laure.fardeau@univ-amu.fr
}

\begin{abstract}
:
A novel obligately anaerobic, non-spore-forming, rod-shaped mesophilic, halophilic, Gram-stainnegative bacterium, was isolated from sediments of Guaymas Basin. The strain, designated Ra1766G1 $1^{\top}$, grew at $20-40{ }^{\circ} \mathrm{C}$ (optimum, $30-35{ }^{\circ} \mathrm{C}$ ) and at $\mathrm{pH}$ 6.0-8.0 (optimum, pH 6.5-7.5). It required $0.5-7.5 \% \mathrm{NaCl}$ (optimum, $2-3 \%$ ) for growth. Sulfate, thiosulfate, elemental sulfur, sulfite, fumarate, nitrate and nitrite were not used as terminal electron acceptors. Strain Ra1766G $1^{\top}$ used cellobiose, glucose, mannose, maltose, arabinose, raffinose, galactose, ribose, sucrose, pyruvate and xylose as electron donors. The main fermentation product from glucose metabolism was acetate. The predominant cellular fatty acids were anteiso- $C_{15: 0}$, iso- $C_{15: 0}$, anteiso DMA- $C_{15: 0}$ and $C_{16: 0}$. The main polar lipids consisted of diphosphatidylglycerol, phosphatidylglycerol, iso-DMA-C $\mathrm{C}_{15: 0}$ glycolipids and phospholipids. The $\mathrm{G}+\mathrm{C}$ content of the genomic DNA was $31.2 \mathrm{~mol} \%$. The closest phylogenetic relatives of strain Ra1766G1 $1^{\top}$ were Natranaerovirga pectinivora AP3 $^{\top}$ (92.4\% $16 \mathrm{~S}$ rRNA gene sequence similarity), Natranaerovirga hydrolytica APP2 ${ }^{\top}(90.2 \%)$ and Defluviitalea saccharophila $6 \mathrm{LT2}{ }^{\top}(88.9 \%)$. On the basis of phylogenetic inference and phenotypic properties, strain Ra1766G1 represents a novel species of a new genus for which the name Vallitalea guaymasensis is proposed. The type strain of the type species is Ra1766G1 ${ }^{\top}\left(=\mathrm{DSM} 24848^{\top}=\mathrm{JCM} 17997^{\top}\right)$.
\end{abstract}

The GenBank/EMBL/DDBJ accession number for the $16 \mathrm{~S}$ rRNA gene sequence of strain Ra1766G1 ${ }^{\top}$ is HE805640. 
The Guaymas Basin hydrothermal site at $2000 \mathrm{~m}$ depth in the Gulf of California is a unique hydrothermal system. At Guaymas Basin, the microbial recycling of fossil organic matter occurs in highly active sediments on a scale of less than a meter, which facilitates sampling, rate measurements and microbial analyses. Molecular analysis based on rRNA, functional genes and lipid biomarkers have revealed a wide range of uncultured bacteria, archaea and eukarya in Guaymas Basin (Edgcomb et al., 2002, Teske et al., 2002). In this paper, we describe a novel mesophilic, anaerobic bacterium, designated as strain Ra1766G $1^{\top}$, isolated from the Guaymas Basin, displaying phenotypic traits that allowed its assignment to a novel species of a novel genus, representing a novel phylogenetic lineage at the family level.

Sediments were collected on the 29 of June 2010 from the Guaymas basin, at the Southern Trough site $\left(27^{\circ} 00^{\prime} 44^{\prime \prime} \mathrm{N}, 111^{\circ} 24^{\prime} 53^{\prime \prime} \mathrm{W}\right.$, at $2002 \mathrm{~m}$ depth), during the BIG 2010 cruise (RV Atalante) using the submersible Nautile (IFREMER, La Seyne-sur-Mer, France). Strain Ra1766 $1^{\top}$ was isolated from white mats on the sediments surface (Supplementary Figure 1), at an in situ temperature of $25^{\circ} \mathrm{C}$. For deployment and recovery, a hermetic tube was used, to avoid washing and mixing. Using the port manipulator of the submersible Nautile, the samples were placed in the submersible insulated basket for the trip to the surface. On board, sediments were stored anaerobically and frozen at $-20^{\circ} \mathrm{C}$ in $10 \% \mathrm{DMSO}$, or directly inoculated in basal medium.

For enrichment and isolation, the basal medium contained (per liter of distilled water) $0.3 \mathrm{~g}$ $\mathrm{KH}_{2} \mathrm{PO}_{4}, 0.3 \mathrm{~g} \mathrm{~K}_{2} \mathrm{HPO}_{4}, 1 \mathrm{~g} \mathrm{NH}_{4} \mathrm{Cl}, 23 \mathrm{~g} \mathrm{NaCl}, 0.1 \mathrm{~g} \mathrm{KCl}, 0.1 \mathrm{~g} \mathrm{CaCl}_{2} .2 \mathrm{H}_{2} \mathrm{O}, 0.5 \mathrm{~g}$ cysteine, $\mathrm{HCl}, 1 \mathrm{~g}$ yeast extract (Difco Laboratories), $1 \mathrm{ml}$ trace mineral element solution (Widdel and Pfennig, 1981) and $1 \mathrm{ml}$ of $0.1 \%$ resazurin (Sigma). The $\mathrm{pH}$ was adjusted to 7.2 with a $10 \mathrm{M}$ $\mathrm{KOH}$ solution. The medium was boiled under a stream of $\mathrm{O}_{2}$-free $\mathrm{N}_{2}$ gas and cooled to room temperature. Aliquots of $5 \mathrm{ml}$ were dispensed into Hungate tubes, degassed under $\mathrm{N}_{2}-\mathrm{CO}_{2}$ $(80 / 20, \mathrm{v} / \mathrm{v})$ and subsequently sterilized by autoclaving at $120{ }^{\circ} \mathrm{C}$ for $20 \mathrm{~min}$. Prior to culture inoculation, $0.1 \mathrm{ml}$ of $10 \%(\mathrm{w} / \mathrm{v}) \mathrm{NaHCO}_{3}, 0.1 \mathrm{ml}$ of $2 \%(\mathrm{w} / \mathrm{v}) \mathrm{Na}_{2} \mathrm{~S} .9 \mathrm{H}_{2} \mathrm{O}, 0.1 \mathrm{ml}$ of $150 \mathrm{~g} / \mathrm{l}$ $\mathrm{MgCl}_{2}, 6 \mathrm{H}_{2} \mathrm{O}$ and $20 \mathrm{mM}$ of glucose from sterile stock solutions were injected into the tubes. The Hungate technique (Hungate, 1969) was used throughout the study.

A $0.5-\mathrm{ml}$ aliquot of the sample was inoculated into the Hungate tubes that were subsequently incubated at $37^{\circ} \mathrm{C}$. To obtain pure cultures, the enrichment was subcultured several times under the same growth conditions prior to isolation. For isolation, the culture was serially diluted tenfold in roll tubes (Miller and Wolin, 1974) containing the same culture medium supplemented with $2 \%$ agar $(\mathrm{w} / \mathrm{v})$. Several colonies developed after incubation at $37^{\circ} \mathrm{C}$ and were picked separately. Colonies were white and circular with diameters ranging from 1.0 to $2.0 \mathrm{~mm}$ after $3-5$ days of incubation at $37^{\circ} \mathrm{C}$. The process of serial dilution was repeated several times until the isolates were deemed to be axenic. Several strains were isolated; their morphology and metabolic profiles were similar and the same phylogenic inference was obtained for all of them. One strain, designated Ra1766G $1^{\top}$, was selected and used for further metabolic and physiological characterization.

Methods for purification of the DNA, PCR amplification and sequencing of the $16 \mathrm{~S}$ rRNA gene were described previously (Ben Dhia Thabet et al., 2004). A sequence of 1444 nucleotides was obtained and deposited in the GenBank database under accession number HE805640. The most closely related sequences were retrieved from the Ribosomal Database Project (release 10) and the GenBank (version 178) using BLAST (Altschul et al., 1990), then aligned using the Muscle program (Edgar, 2004). Phylogenetic analyses were conducted in MEGA5 (Tamura et al, 2011) and computed using the Maximum Likelihood method (Tamura et al, 2004) (Fig. 1). The analysis involved 75 nucleotide sequences. All ambiguous positions were removed for each sequence pair. There were a total of 1869 positions in the final dataset. Tree topology was re-examined by the bootstrap method (500 replications) of resampling 
(Felsenstein, 1985). Its topology was also supported using the neighbor-joining and maximum-parsimony algorithms.

Strain Ra1766G $1^{\top}$ shared $92.4 \%$ similarity with the type strain Natranaerovirga pectinovirga isolated from sediments of hypersaline soda lakes from the Kulunda Steppe (Sorokin et al, 2012) and $88.9 \%$ similarity with Defluviitalea saccharophila isolated from an up flow anaerobic filter treating abattoir wastewaters in Tunisia (Jabari et al., 2012).

Growth experiments were performed in duplicate, using Hungate tubes containing the basal medium. The $\mathrm{pH}$, temperature, and $\mathrm{NaCl}$ concentration ranges for growth were determined using basal medium. The $\mathrm{pH}$ of the medium was adjusted by injecting in Hungate tubes aliquots of anaerobic stock solutions of $1 \mathrm{M} \mathrm{HCl}$ (acidic pHs), $10 \% \mathrm{NaHCO}_{3}$ or $\mathrm{Na}_{2} \mathrm{CO}_{3}$ (alkaline pHs) (to test pH between 5 and 8.6) and checked after autoclaving. Water baths were used for incubating bacterial cultures from $20^{\circ} \mathrm{C}$ to $55^{\circ} \mathrm{C}$, with increments of $5^{\circ} \mathrm{C}$. To study the requirement of $\mathrm{NaCl}, \mathrm{NaCl}$ was weighed directly in the tubes $(0-10 \%)$ before the medium was dispensed. The strain was subcultured at least twice under the same experimental conditions before the growth rates were determined. Arabinose, cellobiose, glucose, fructose, galactose, ribose, glycerol, lactose, maltose, mannitol, mannose, raffinose, rhamnose, saccharose, xylose, peptone, casaminoacids, acetate, succinate, butyrate, formate, lactate and pyruvate, were tested as electron donors. Each substrate was added to the basal medium at a final concentration of $20 \mathrm{mM}$ whereas $\mathrm{H}_{2} / \mathrm{CO}_{2}(80 / 20)$, or $\mathrm{H}_{2} / \mathrm{CO}_{2}$ $(80 / 20)$ in the presence of acetate $(2 \mathrm{mM}$ acetate), was tested at 2 bars. Elemental sulfur (1 $\% \mathrm{w} / \mathrm{v})$, sodium sulfate $(20 \mathrm{mM})$, sodium thiosulfate $(20 \mathrm{mM})$, Na sulfite $(2 \mathrm{mM})$, fumarate $(20 \mathrm{mM})$, sodium nitrate $(10 \mathrm{mM})$ and sodium nitrite $(2 \mathrm{mM})$, were tested as terminal electron acceptors. $\mathrm{H}_{2} \mathrm{~S}$ production was determined photometrically as colloidal CuS by using the method of Cord-Ruwisch (1985).

Bacterial growth was monitored by measuring the increase in turbidity at $580 \mathrm{~nm}$ by insertion of Hungate tubes into the cuvette holder of a spectrophotometer (Cary 50, Varian). Endproducts of metabolism were measured by high pressure liquid chromatography (HPLC) and gas chromatography of the gases released after 2 weeks of incubation at $37^{\circ} \mathrm{C}$ (Fardeau et al., 2000).

Cellular morphology and purity of the strains were assessed under an Optiphot (Nikon) phase-contrast microscope. For transmission electron microscopy studies, cells were negatively stained with sodium phosphotungstate, as previously described (Fardeau et al., 1997). The presence of spores was checked by microscopic observation of cultures and pasteurization tests performed at 80,90 and $100{ }^{\circ} \mathrm{C}$ for 10 and $20 \mathrm{~min}$.

Cells of strain Ra1766G $1^{\top}$ stained Gram-negative (Gram staining reaction) and had a multilayered cell-wall and an outer membrane typical of Gram-negative bacteria (Gram type based on cell wall analysis). The cells were non motile, non-spore-forming rods (Supplementary Figure $2 \mathrm{~A}, \mathrm{~B}, \mathrm{C}$ ). The phenotypic characteristics of strain Ra1766G $1^{\top}$ are listed in the genus and species descriptions and Table 1. The isolate required yeast extract for growth which could be replaced by biotrypcase or vitamins of Balch (Balch et al., 1979). However, growth was better in presence of yeast extract.

Analysis of the respiratory quinones and polar lipid analyses were carried out by Dr Brian Tindall at the Identification Service of the DSMZ (Braunschweig. Germany). For fatty acid analysis, the biomass of strain Ra1766 $1^{\top}$ was standardized for its physiological age at the point of harvest according to Technical Note 101 of MIDI (http://www.microbialid.com/PDF/TechNote_101.pdf). Fatty acids were extracted using the method of Miller (1982) with the modifications of Kuykendall et al. (1988) and analysed by gas chromatography (model 6890N, Agilent Technologies) using the Microbial Identification System (MIDI, Sherlock Version 6.1; database, TSBA40). DNA was isolated and purified by 
chromatography on hydroxyapatite using the procedure of Cashion et al. (1977) and the $G+C$ content was determined by using HPLC (Mesbah et al., 1989).

The major fatty acids were: anteiso- $\mathrm{C}_{15: 0}(22.7 \%)$, iso- $\mathrm{C}_{15: 0}(13.7 \%)$, anteiso DMA- $\mathrm{C}_{15: 0}$ $(10.8 \%)$ and $\mathrm{C}_{16: 0}(7.0 \%)$. No quinones were detectable and the polar lipid profile of strain Ra1766 $\mathrm{G}^{\top}{ }^{\top}$ consisted of diphosphatiglycerol, phosphatidylglycerol, two glycolipids, two phospholipids, and a range of unidentified glyco and phospholipids. (Table 2; Supplementary Figure 3 ). The $\mathrm{G}+\mathrm{C}$ content of the genomic DNA of strain Ra1766G1 ${ }^{\top}$ was $31.2 \%$ (Table 1 ). Based on an inferred phylogenetic tree, the closest cultured relatives of strain Ra1766G $1^{\top}$ are Defluviitalea saccharophila (Jabari et al., 2012), a member of the family Defluviitaleacea and Natranaerovirga pectinivorga, not classified in a family. But the two strains differ of strain Ra $1766 \mathrm{G} 1^{\top}$ by several points (Tables 1 and 2 ). D. saccharophila is Gram positive and grows at $50-55{ }^{\circ} \mathrm{C}$. Natranaerovirga pectinivorga is also Gram positive and grows at $43^{\circ} \mathrm{C}$, is alkaliphilic and presents a very narrow substrate spectrum for growth, restricted to galacturonic acid and its polymer (e.g. pectin). Strain Ra $1766 \mathrm{G} 1^{\top}$ is Gram negative and grows at $30-35{ }^{\circ} \mathrm{C}$. The $\mathrm{G}+\mathrm{C} \%$ is also different and the profiles of polar lipids and of fatty acids differ too. The association of the novel isolate with the genus Natranaerovirga could be evident from the RDP classifier, which gave $92.8 \%$ probability with the clustering. Nevertheless, there are too many differences between the strains and the position of the novel isolate will remain uncertain until more sequences of related organisms appear in the database.

Therefore, on the basis of phylogenetic inference and phenotypic characteristics, we propose that strain $\mathrm{Ra} 1766 \mathrm{G} 1^{\top}$ represents a novel species of a novel genus and was proposed as Vallitalea guaymasensis .

\section{Description of Vallitalea gen. nov.}

Vallitalea: Val.li.ta'le.a. L. n. vallis, a valley, vale; L. fem. n. talea, a rod; N.L. fem. n. Vallitalea, a rod isolated from a vale.

Cells stain Gram-negative (Gram staining reaction). Non-motile, non-spore-forming, mesophilic, rods with a fermentative and obligately anaerobic type of metabolism. No quinones detectable, and the major fatty acids are : anteiso- $C_{15: 0}$, iso- $C_{15: 0}$, anteiso DMA- $C_{15: 0}$ and $\mathrm{C}_{16: 0}$. The DNA G+C content of the type strain of the type species is $31.2 \mathrm{~mol} \%$ The type species is Vallitalea guaymasensis.

\section{Description of Vallitalea guaymasensis sp. nov.}

guaymasensis: guay.mas.en'sis. N.L. fem. adj. guaymasensis, of or belonging to Guaymas.

Displays the following characteristics in addition to those listed in the genus description. Cells are rods approximately 2 to $10 \mu \mathrm{m}$ in length and 0.5 to $1 \mu \mathrm{m}$ in diameter, occurring singly or in pairs. Growth occurs at $20-40{ }^{\circ} \mathrm{C}$, (optimum, $30-35^{\circ} \mathrm{C}$ ), at pH 6.0-8.0 (optimum, pH 6.57.5 ) and at $\mathrm{NaCl}$ concentration $0.5 \%-7.5 \%$ (optimum, $2 \%-3 \%$ ). Yeast extract is required for growth. Cellobiose, glucose, mannose, maltose, arabinose, raffinose, galactose, ribose, saccharose, pyruvate and xylose are used as electron donors, but glycerol, mannitol, casaminoacids, acetate, lactate, fructose, succinate, butyrate, peptone, lactose, rhamnose, formate, $\mathrm{H}_{2} / \mathrm{CO}_{2}$, or $\mathrm{H}_{2} / \mathrm{CO}_{2}$ in the presence of acetate are not. The main fermentation product from glucose metabolism was acetate. Sulfate, thiosulfate, elemental sulfur, sulfite, nitrate and nitrite were not used as terminal electron acceptors. Contains significant amounts of anteiso- $\mathrm{C}_{15: 0}$, iso- $\mathrm{C}_{15: 0}$, anteiso DMA-C $\mathrm{C}_{15: 0}$ and $\mathrm{C}_{16: 0}$. The $\mathrm{G}+\mathrm{C}$ content of the genomic DNA of the type strain is $31.2 \mathrm{~mol} \%$. The type strain, Ra1766G1 $1^{\top}\left(=\mathrm{DSM} 24848^{\top}=\mathrm{JCM} 17997^{\top}\right)$ was isolated from sediments of Guaymas basin. 


\section{Acknowledgments}

We thank Dr. Jean Euzéby for checking the Latin etymology of genus and species names, Manon Joseph from IRD and Alain Bernadac from CNRS for electronic microscopy.We are grateful to the captain and crew of RV Atalante, and team operating the submersible Nautile (IFREMER, La Seyne-sur-Mer, France). This BIG 2010 cruise (Anne Godfroy and Daniel Prieur, chief scientists was funded by IFREMER (France) and has benefited from a work permit in Mexican waters (DAPA/2/281009/3803, October 28th, 2009).

\section{References}

Altschul, S.F., Gish, W., Miller, W., Myers, E.W. \& Lipman, D.J. (1990). Basic local alignment search tool. $J$ Mol Biol 215, 403-410.

Balch, W.E., Fox, G.E., Magrum, L.J., Woese, C.R. \& Wolfe, R. S. (1979). Methanogens: reevaluation of a unique biological group. Microbiol Rev 43, 260-296.

BenDhia Thabet, O., Fardeau, M-L, Joulian, C., Thomas, P., Hamdi, M., Garcia, J-L. \& Ollivier, B. (2004). Clostridium tunisiense sp. nov., a new proteolytic, sulfur-reducing bacterium isolated from an olive mill wastewater contaminated by phosphogypse. Anaerobe 10, 185-190.

Cashion, P., Holder-Franklin, M. A., McCully, J. \& Franklin, M. (1977). A rapid method for the base ratio determination of bacterial DNA. Anal Biochem 81, 461-466.

Cord-Ruwisch, R. (1985). A quick method for the determination of dissolved and precipitated sulfides in cultures of sulfate-reducing bacteria. J Microbio Methods 4, 33-36.

Edgar, R.C. (2004). MUSCLE: multiple sequence alignment with high accuracy and high throughput. Nucl Acids Res 32, 1792-1797.

Edgcomb, V.P., Kysela D., Teske A., de Vera Gomez A., \& Sogin M. L. (2002). Benthic eukaryotic diversity in the Guaymas Basin hydrothermal vent environment. PNAS 99, 76587662.

Fardeau, M-L., Ollivier, B., Patel, B.K.C., Magot, M., Thomas, P., Rimbault, A., Rocchiccioli, F. \& Garcia, J-L. (1997). Thermotoga hypogea sp. nov., a xylanolytic, thermophilic bacterium from an oil-producing well. Int J Syst Evol Microbiol 47, 1013-1019.

Fardeau, M-L., Magot, M., Patel, B. K. C., Thomas, P., Garcia, J-L. \& Ollivier, B. (2000). Thermoanaerobacter subterraneus sp. nov., a novel thermophile isolated from oilfield water. Int J Syst Evol Microbiol 50, 2141-2149.

Felsenstein, J. (1985). Confidence limits on phylogenies: An approach using the Bootstrap. Evolution 39, 783-791.

Hungate, R. E. (1969). A roll-tube method for the cultivation of strict anaerobes. Methods Microbiol 3B, 117-132.

Jabari, L., Gannoun, H., Cayol, J-L., Hamdi, M., Fauque, G., Ollivier, B. \& Fardeau M-L. (2012). Characterization of Defluviitalea saccharophila gen. nov., sp. nov., a thermophilic bacterium isolated from an upflow anaerobic filter treating abattoir wastewaters, and proposal of Defluviitaleaceae fam. nov. Int J Syst Evol Microbiol 62, 550-555.

Kuykendall, L. D., Roy, M. A., O’Neil, J. J., \& Devine, T. E. (1988). Fatty acids, antibiotic resistance, and desoxyribonucleic acid homology groups of Bradyrhizobium japonicum. Int $J$ Syst Bacteriol 38, 358-361.

Mesbah, M., Premachandran U. \& Whitman, W. B. (1989). Precise measurement of the $\mathrm{G}+\mathrm{C}$ content of deoxyribonucleic acid by high-performance liquid chromatography. Int $J$ Syst Bacteriol 39, 159-167.

Miller, L. T. (1982). Single derivatization method for routine analysis of bacterial whole-cell fatty acid methyl esters, including hydroxy acids. J Clin Microbiol 16, 584-586. 
Miller, T.L., \& Wolin, M.J. (1974). A serum bottle modification of the Hungate technique for cultivating obligate anaerobes. Appl Microbiol 27, 985-987.

Saitou, N. \& Nei, M. (1987). The neighbor-joining method: a new method for reconstructing phylogenetic trees. Mol Biol Evol 4, 406-425.

Sorokin, D.Y., TRourova, T.P., Panteleeva, A.N., Kaparullina, E.N. \& Muyzer, G. (2012). Anaerobic utilization of pectinous substrates at extremely haloalkaline conditions by Natranaerovirga pectinivora gen. nov., sp. nov., and Natranaerovirga hydrolytica sp. nov., isolated from hypersaline soda lakes. Extremophiles, 16, 307-315.

Tamura, K., Nei, M., \& Kumar, S. (2004). Prospects for inferring very large phylogenies by using the neighbor-joining method. Proc Natl Acad Sci (USA) 101, 11030-11035.

Tamura K., Peterson D., Peterson N., Stecher G., Nei M., \& Kumar S. (2011). MEGA5: Molecular evolutionary genetics analysis using maximum likelihood, evolutionary distance, and maximum parsimony methods. Mol Biol Evol (In Press).

Teske, A., K-U. Hinrichs, V. Edgcomb, A. de Vera Gomez, D. Kysela, S. P. Sylva, M. L. Sogin, \& Jannasch, H. W. (2002). Microbial diversity in hydrothermal sediments in the Guaymas Basin: evidence for anaerobic methanotrophic communities. Appl Environ Microbiol 68, 1994-2007.

Widdel, F. \& Pfennig, N. (1981). Studies on dissimilatory sulphate reducing bacteria that decompose fatty acids. I. Isolation of new sulfate-reducing bacteria enriched with acetate from saline environments. Description of Desulfobacter postgatei gen. nov., sp. nov. Arch Microbiol 129, 395-400. 
Figure 1. Phylogenetic position of strain Ra $1766 \mathrm{G} 1^{\top}$ within the Clostridiales based on $16 \mathrm{~S}$ rRNA gene sequence analysis using the NeighborJoining method. The analysis involved 75 nucleotide sequences. There were a total of 1869 positions in the final dataset. Numbers at node indicate bootstrap values above 60\% (bootstrap test from 500 replicates). Scale bar: 0.01 substitutions per site.

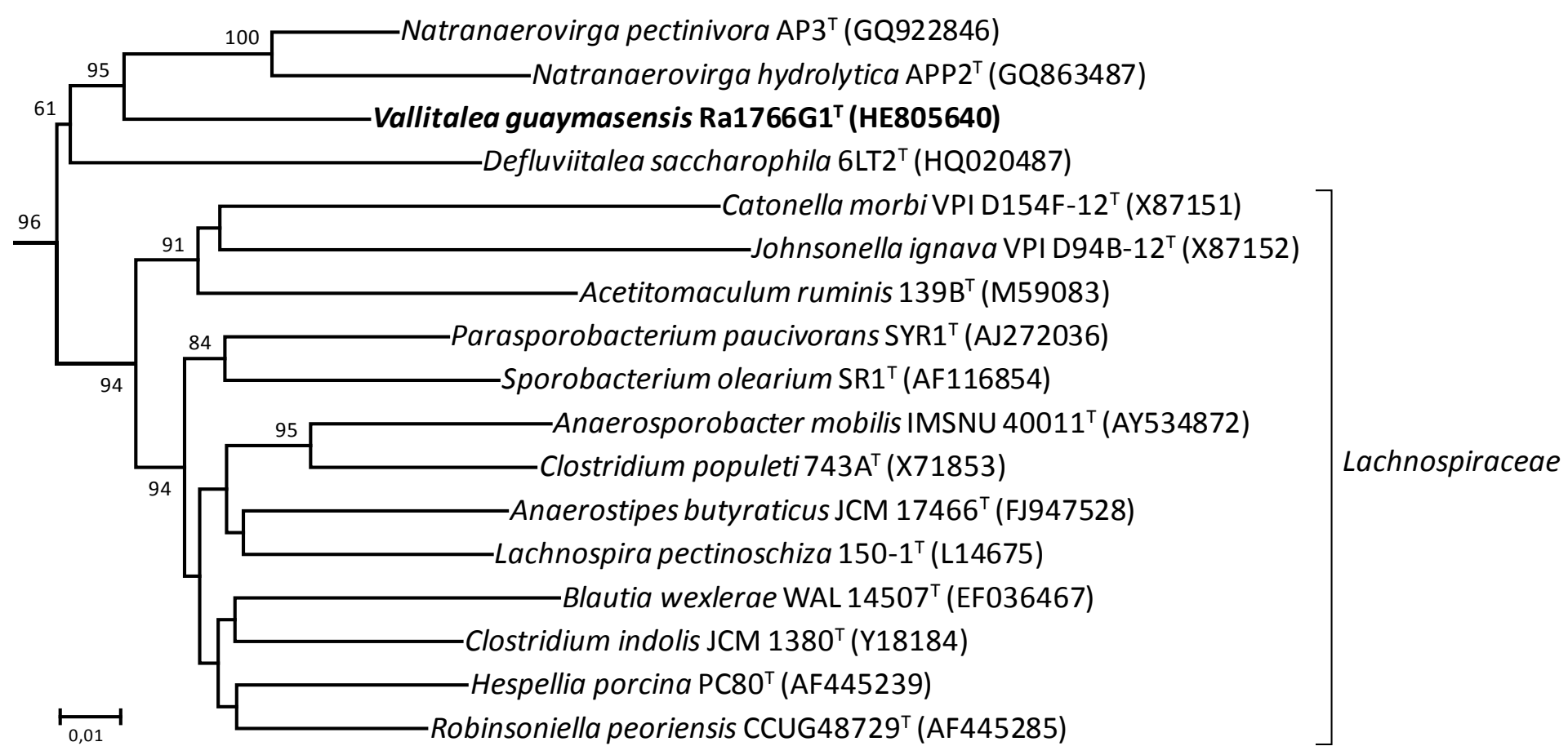


Table 1. Differential characteristics between strain Ra1766G $1^{\top}$, Defluviitalea saccharophila ${ }^{T}$, and Natranaerovirga pectinivorga ${ }^{T}$.

\begin{tabular}{|c|c|c|c|}
\hline Characteristics & Strain Ra1766G1 ${ }^{\top}$ & $\begin{array}{l}\text { Defluviitalea } \\
\text { saccharophila }^{T}\end{array}$ & $\begin{array}{l}\text { Natranaerovirga } \\
\text { pectinivorga }^{T}\end{array}$ \\
\hline Gram stain & - & + & + \\
\hline $\begin{array}{l}\text { Optimum } \\
\text { temperature }\left({ }^{\circ} \mathrm{C}\right)\end{array}$ & $30-35$ & $50-55$ & 43 \\
\hline Optimum pH & $6.5-7.5$ & $7-7.5$ & $9.5-9.7$ \\
\hline Optimum $\mathrm{NaCl}(\%)$ & $2-3$ & 0.5 & 2 \\
\hline $\begin{array}{lll}\mathrm{G}+ & \mathrm{C} & \text { content } \\
(\mathrm{mol} \%) & & \end{array}$ & 31.2 & 35.2 & 30.7 \\
\hline $\begin{array}{l}\text { Main substrates } \\
\text { used } \\
\text { Cellobiose, } \\
\text { arabinose, } \\
\text { raffinose } \\
\text { glucose, } \\
\text { mannose, } \\
\text { maltose, } \\
\text { mannitol, } \\
\text { saccharose, } \\
\text { xylose, } \\
\text { pyruvate }\end{array}$ & $\begin{array}{l}\text { Carbohydrates } \\
+ \\
+ \\
+ \\
+ \\
+ \\
+ \\
+ \\
+ \\
+ \\
+\end{array}$ & $\begin{array}{l}\text { Carbohydrates } \\
+ \\
- \\
- \\
+ \\
+ \\
+ \\
+ \\
+ \\
+ \\
-\end{array}$ & $\begin{array}{l}\text { Galacturonic acid } \\
\text { and pectin } \\
- \\
- \\
- \\
- \\
- \\
- \\
- \\
- \\
-\end{array}$ \\
\hline $\begin{array}{l}\text { End products of } \\
\text { fermentation }\end{array}$ & acetate & $\begin{array}{l}\text { formate, acetate, } \\
\text { butyrate, } \\
\text { isobutyrate }\end{array}$ & acetate, formate \\
\hline Polar lipids & PG, DPG, PL, GL & $\begin{array}{l}\text { PG, DPG, } \quad \text { PL, } \\
\text { GL, PGL }\end{array}$ & $\begin{array}{l}\text { PG, DPG, PL, GL, } \\
\text { APL }\end{array}$ \\
\hline
\end{tabular}


Table 2. Cellular fatty acid profile (\%) of strains Ra1766G $1^{\top}$, Defluviitalea saccharophila ${ }^{\top}$, and Natranaerovirga pectinivorga ${ }^{T}$

Fatty acids amounting to less than $1 \%$ are not shown.

The summed feature 13 consisted of $C_{15: 0}$ anteiso DMA.

\begin{tabular}{|c|c|c|c|}
\hline Cellular fatty acid & Strain Ra1766G1 ${ }^{\top}$ & $\begin{array}{l}\text { Defluviitalea } \\
\text { saccharophila }^{T}\end{array}$ & $\begin{array}{l}\text { Natranaerovirga } \\
\text { pectinivorga }^{T}\end{array}$ \\
\hline $\mathrm{C}_{13: 0 \text { iso }} 3 \mathrm{OH}$ & 1.5 & & \\
\hline $\mathrm{C}_{14: 0}$ DMA & 2.2 & & \\
\hline$C_{14: 0 \text { iso }}$ & 2.7 & & \\
\hline $\mathrm{C}_{14: 0}$ & 2.6 & 8.3 & - \\
\hline$C_{15: 0}$ iso DMA & 10.0 & & \\
\hline $\mathrm{C}_{15: 0}$ anteiso & 22.7 & & \\
\hline$C_{16: 0}$ & 7.0 & 68.4 & 46.9 \\
\hline$C_{16: 0}$ iso & 2.4 & & \\
\hline Sum in feature 13 & 10.8 & & \\
\hline$C_{18: 0}$ & & 7.3 & \\
\hline$C_{16: 1} \operatorname{cis} 9$ & & 5.3 & \\
\hline C18:1 w7c & & 4.1 & 17.5 \\
\hline$C_{16: 0 \mathrm{DMA}}$ & 5.5 & & \\
\hline $\mathrm{C}_{15: 0}$ iso & 13.7 & & \\
\hline
\end{tabular}

Supplementary Figure 1. Sediment sampling at the Southern trough site, on the 29 of June 2010, at the Guaymas basin, by the submersible Nautile. Arrow: white mats at the sediments surface.

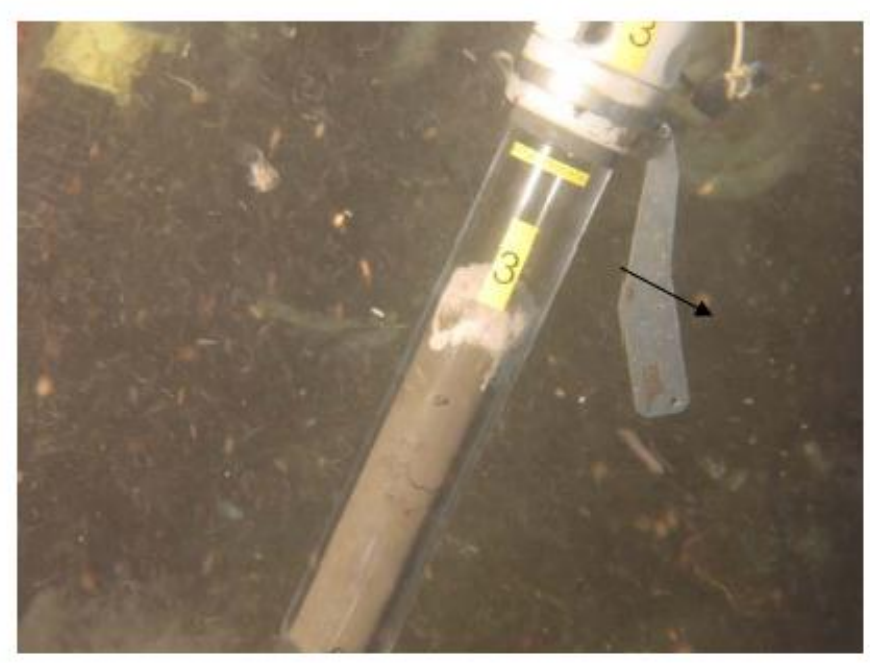


Supplementary Figure 2. Cell morphology of strain Ra1766G1 $1^{\top}$. A, phase-contrast micrograph (bar, $20 \mu \mathrm{m})$; B (bar, $1 \mu \mathrm{m}$ ) and C (bar, $0.2 \mu \mathrm{m})$ : thin-section electron micrographs showing the Gram-negative type of cell wall.
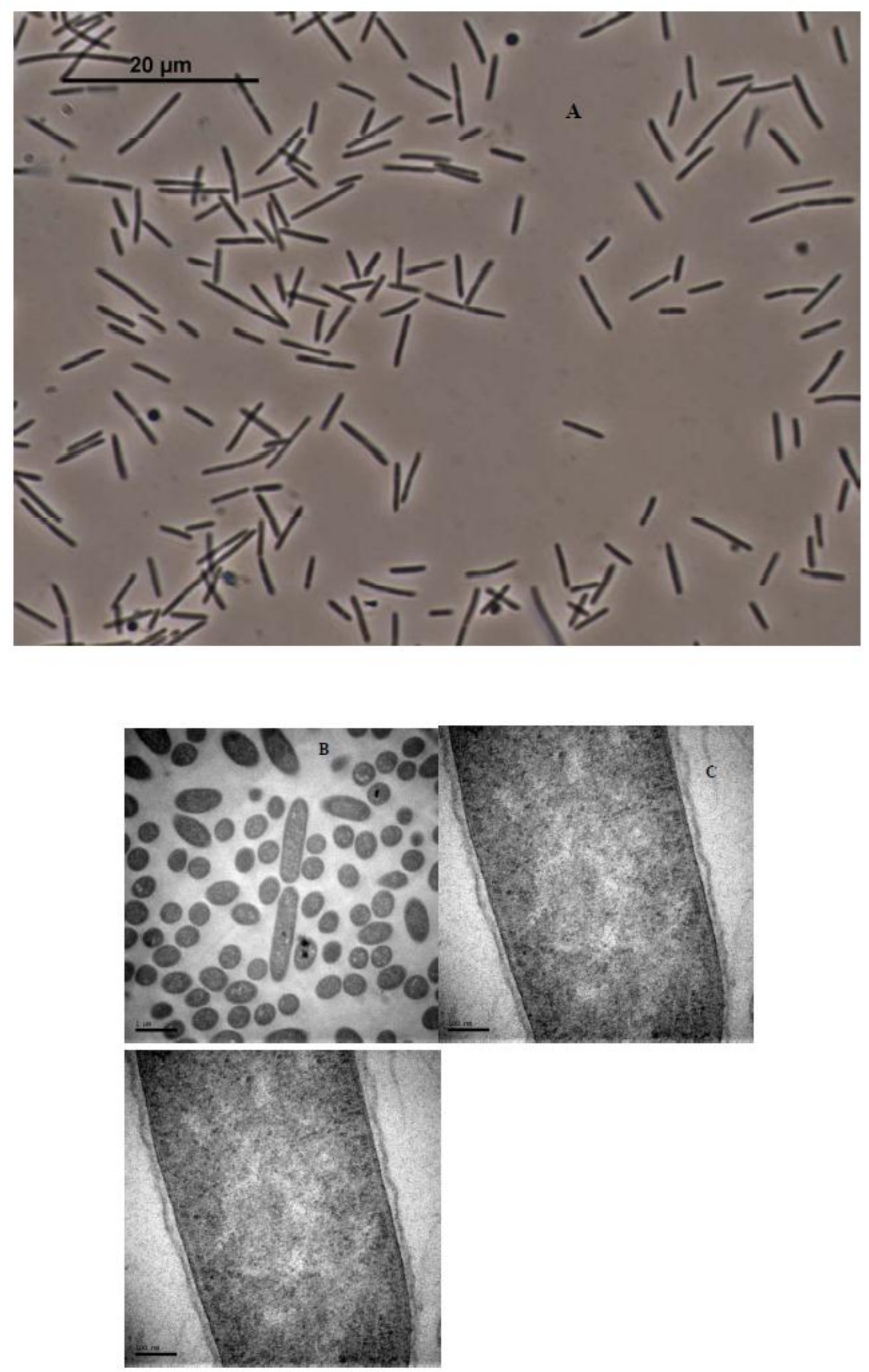
Supplementary Figure 3. Total polar lipids of strain Ra $1766 \mathrm{G} 1^{\top}$ after two-dimensional TLC and detection with molybdatophosphoric acid and heating at $200{ }^{\circ} \mathrm{C}$ for 10 minutes. DPG, diphosphatidylglycerol, PG phosphatidylglycerol, PL1-4, phospholipids, GL1-2, glycolipids, PGL phosphoglycolipids, APL aminophospholipids.

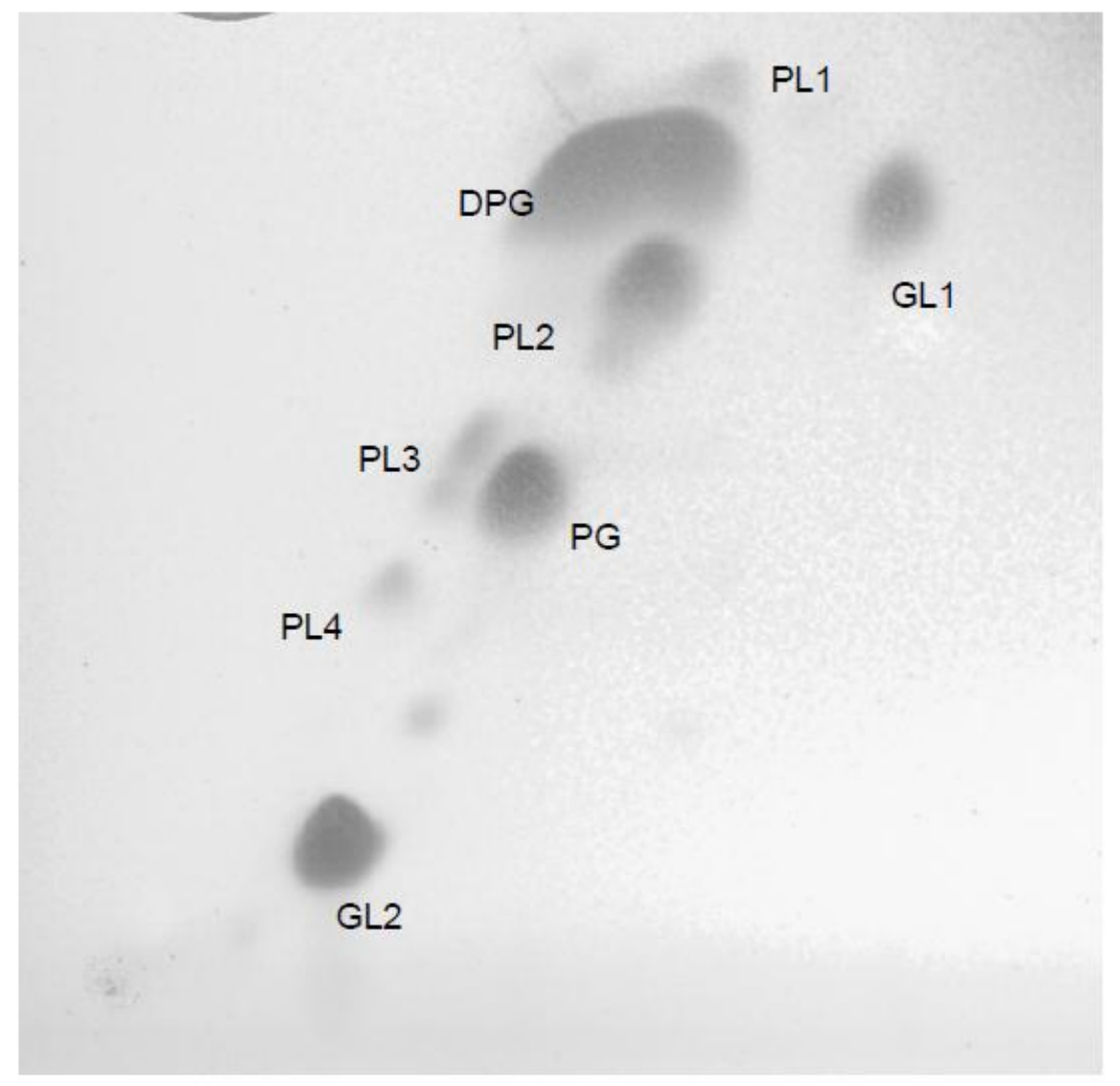

